\begin{tabular}{|c|c|c|}
\hline & Int.J.Curr.Microbiol.App.Sci (2021) 10(08): 365-367 & \\
\hline & $\begin{array}{l}\text { International Journal of Current Microbiology and Applied Sciences } \\
\text { ISSN: 2319-7706 Volume } \mathbf{1 0} \text { Number } \mathbf{0 8} \mathbf{( 2 0 2 1 )} \\
\text { Journal homepage: http://www.ijcmas.com }\end{array}$ & $\$ 2$ \\
\hline $\begin{array}{l}\text { EXCELLENT } \\
\text { PUBLISHERS }\end{array}$ & & wuwwijemas.com \\
\hline
\end{tabular}

Case Study

https://doi.org/10.20546/ijcmas.2021.1008.044

\title{
Cyniclomyces Related to Comportamental Disturb in Dog: Case Report
}

\author{
Elizabeth Simões do Amaral Alves ${ }^{1}$, José Sérgio da Silva ${ }^{1}$, \\ Walter Franklin Bernadino Leão Filho², Kelmanny Crislen Ferreira Sousa ${ }^{2}$, \\ Fabrícia Duarte Omena ${ }^{3}$ and João Manoel da Silva ${ }^{4}$
}

\author{
${ }^{1}$ Department of Animal Morphology and Physiology, Veterinarian, Federal Rural University \\ of Pernambuco - UFRPE, Brazil \\ ${ }^{2}$ Veterinarian, Universidade Federal de Alagoas - UFAL, Brazil \\ ${ }^{3}$ Veterinarian, Centro de Estudos Superiores de Maceió-CESMAC, Brazil \\ ${ }^{4}$ Department of Biotechnology, Agronomist Engineer, \\ Centro de Ciências Agrárias - CECA, Brazil \\ *Corresponding author
}

\section{A B S T R A C T}

Keywords

Gastrointestinal tract, coprophagy, canine

Article Info

Accepted:

20 July 2021

Available Online:

10 August 2021
Cyniclomyces guttulatus is a commensal ascomycete fungus identified in the natural microbiota of rabbits and other herbivores, as well as being present in cases of diarrhea in rabbits. In the literature, this agent is described in dogs as responsible for suppurative cholecystitis and/or cholangiohepatitis, chronic gastritis, and its presence is currently occurring in the feces of animals with diarrhea or even in healthy animals, but its clinical importance has not yet been fully elucidated. This study aimed to report the case of a healthy dog of the Shih Tzu breed, 2 months old, not neutered, weighing $2 \mathrm{~kg}$, affected by ascomycete of the genus Cyniclomyces related to the direct cause of the practice of coprophagy.

\section{Introduction}

Cyniclomyces guttulatus is a commensal ascomycete fungus identified in the natural microbiota of the mucosal layer of the gastric fundus and pylorus of rabbits and other herbivores, causing diarrhea where they are released into the environment, remaining viable for a long period in the form of ascopores (Ferraz et al., 2019). In the medical routine of small animals, diarrhea is one of the most frequent clinical signs of disorders of the gastrointestinal tract, with varied etiologies: bacterial, viral, parasitic, toxin-infections and fungal, which can be diagnosed through coproparasitological, where it is possible to identify agents possibly pathogens, such as Cyniclomyces guttulatus (Ferraz et al., 2020).

Thus, the isolation of Cyniclomyces as a cause of diarrheal conditions and its clinical importance has not yet been fully elucidated, 
but it is believed to be related to gastrointestinal disorders, as a primary or opportunistic agent (Alves et al., 2018).

The presence of Cyniclomyces has been found, in the stomach associated with suppurative cholecystitis and/or cholangiohepatitis, in dogs with chronic gastritis through gastric lavage, but mainly its presence has been occurring in the feces of animals with diarrhea or in healthy animals (Furtado et al., 2013). Thus, this study aimed to report the case of a healthy dog affected by ascomycete of the genus Cyniclomyces, related to the behavioral disorder of coprophagy.

\section{Case Report}

On 07/27/2020, a 2-month-old male Shih Tzu breed dog was treated, weighing $2 \mathrm{~kg}$, dewormed, first administered polyvalent vaccine, complaining of coprophagy in a Veterinary Hospital in the city of ArapiracaAlagoas, Brazil.

During the physical examination, the patient had normal physiological parameters, in the anamnesis, normal water and urine intake was reported, present appetite, exclusive feeding of super premium food in the amount recommended by the manufacturer, whose tutor emphasized smelly evacuation and ingestion of feces.

Hemogram was requested that showed mild thrombocytosis and stool coproparasitological that identified the presence of three crosses $(+++)$ compatible with ascomycete of the genus Cyniclomyces, where oral antifungal therapy of fluconazole was instituted at a dose of $5 \mathrm{mg} / \mathrm{kg}$, SID (1x per day) for 30 days. After the treatment was completed, the patient returned to the veterinary hospital to repeat the tests, where the blood count showed no change and the fecal coproparasitology was negative.

\section{Results and Discussion}

Among the main causes of coprophagy, we can mention: poor quality food, insufficient quantity, unbalanced diet, gastrointestinal parasites, exocrine pancreatitis, vitamin B1 (thiamine) deficiency, behavioral causes such as, for example: separation anxiety, bored dogs that handle feces as a hobby, punishment of the person responsible for finding feces in inappropriate places, and the animal ingesting them in order to hide them, are examples of the reasons that justify this behavioral disorder (Melo and Scheraiber, 2015).

Cyniclomyces was related to the direct cause of coprophagy, in this report, where we can raise two factors: the bad smell as an attraction caused by the large presence identified in the feces coproparasitology; as well as due to the fact that the population imbalance of the intestinal microbiota compromises the physiological fermentation process and nutrient absorption, resulting in the need for ingestion of feces for compensation.

In Brazil, the genus Cyniclomyces is rarely reported, but it is believed that there is underreporting of diagnoses. The literature describes the involvement of pathologies in the gastric, hepatobiliary and enteritis systems, but its pathogenesis as a primary or opportunistic agent in the dynamics of the lesions that this ascomycete causes in the tissues has not yet been defined.

The response of the study patient to treatment with $5 \mathrm{mg} / \mathrm{kg}$ of oral fluconazole SID for 30 days was satisfactory, where the instituted therapy eliminated the agent, the odor of feces as well as its ingestion, which, in addition to providing reinfection of intestinal parasites, was a reason too much of an inconvenience for the tutor. In that report, there is a new hypothesis of cause for coprophagy in the clinic of small animals, highlighting the 
importance of the fecal stool examination, which was essential to identify the genus Cyniclomyces in a clinically healthy patient, and the efficacy of fluconazole as a therapeutic single, more studies should be carried out on the relationship of this agent and its pathogenicity.

\section{References}

Alves, P. V., Vasconcelos, J. G., Gomes, K. E. P., Magalhães, H. K. N., Camelo, K. S., Viana Neto, R. L. (2018) Infecção por Cyniclomyces guttulatus em cão. Ciênc. Anim., 28(4): 71-73.

Ferraz, A., Pires, B. S., Barwaldt, E. T., Dos Santos, E. M., Dallmann, P. R. J., De Castro, T. A., Nizole, L. Q. (2020) Cyniclomyces guttulatus em amostras fecais de cães: infecção simples e multiparasitismo. Res. Soc. Develop.,
9(4): e115942920.

Ferraz, A., Pires, B. S., Dos Santos, E. M., Evaristo, T. A., Nobre, M. O., Nizole, L.Q. (2019) Presença de Cyniclomyces guttulatus em amostra fecal de cão com diarreia crônica. Relato de caso. Rev. Bras. Hig. San. Anim., 13(2): 24651.

Furtado, T. T., Flausino, G., Leal, P. D. S., Ferreira, J. P., Mcintosh, D., Flausino, W., Filho, W. L. T., Paes-De-Almeida, E. C., Lopes, C. W. G. (2013) Diagnóstico de Colangite associado à mucocele da vesícula biliar por Cyniclomyces guttulatus em cães Relato de caso. Rev. Bras. Med. Vet., 35(1): 1-6.

Melo, I., Scheraiber, M. (2015) Coprofagia em cães - artigo de revisão. Rev. Elet. Bioci. Biotecnol. Saúde, 1(12): 142144.

\section{How to cite this article:}

Elizabeth Simões do Amaral Alves, José Sérgio da Silva, Walter Franklin Bernadino Leão Filho, Kelmanny Crislen Ferreira Sousa, Fabrícia Duarte Omena and João Manoel da Silva. 2021. Cyniclomyces Related to Comportamental Disturb in Dog: Case Report. Int.J.Curr.Microbiol.App.Sci. 10(08): 365-367. doi: https://doi.org/10.20546/ijcmas.2021.1008.044 